\title{
The Estrous Cycle and Induction of Ovulation in Mares
}

\author{
Minjung Yoon \\ Division of Animal Science and Biotechnology, Kyungpook National University, Sangju, 742-711, Korea
}

\begin{abstract}
For horse breeders or managers, it is critical to understand the estrous cycle of mares. Breeding of mares cannot be successfully achieved throughout the whole year as mares breed seasonally. Mares are only able to breed when day length is more than $16 \mathrm{~h}$, and this period is known as the breeding season. Their estrous cycle is approximately 21 days with 5-7 days of estrus and 14 to 15 days of a diestrus period. The estrous cycle of the mare is mainly controlled by gonadotropins, which control follicular development and ovulation. Mares exhibit unique ovulatory events which are not observed in other species. A LH surge occurs for several days, with levels of LH reaching their peak after ovulation. The LH level at the time of LH peak is lower than most other species. The unique anatomical structure of the ovaries of mares is known to limit the number of eggs ovulated. Several attempts have been made to develop chemical/hormonal agents which might be used to manipulate the timed ovulation of mares. Agents that have been tested include hCG, native GnRH, Deslorelin (Ovuplant, GnRH-agonist), Buserelin (GnRH analogue), equine pituitary extracts and equine chorionic gonadotropin (eCG or PMSG). However, the function, purity or stability of these agents is not reliable. Recombinant equine LH, an alternative agent for the timed ovulation, has been developed and tested for its biological activities, through the use of both in vitro and in vivo experiments. The reLH was suggested to be a reliable agent in inducing ovulation within $48 \mathrm{~h}$ after being administered through injection, when the size of dominant follicle is $35 \mathrm{~mm}$ in diameter.
\end{abstract}

(Key words : Mares, Estrous cycle, Follicular development, Ovulation, Timed ovulation)

\section{INTRODUCTION}

For the successful breeding of horses, an understanding of the physiological changes in the reproductive status of mares is critical. With such knowledge of the physiological status of mares, horse breeders can better manage the breeding and husbandry of the animals, and significantly improve fertility rates. Physiological changes which including that of the estrous cycle, follicular development and ovulation should be monitored daily by the horse breeder. By monitoring a mares' estrous cycle, a breeder can anticipate the time of ovulation and can inseminate the animal at the right time. Timing is critical for both proper fertilization, and a higher pregnancy success rate, due to the short span of the viability of ovum and sperm. After ovulation, there is just a 6 to 12 $\mathrm{h}$ window available in which the ovum may be fertilized. The longevity of ejaculated sperm within the female reproductive tract is $48 \mathrm{~h}$, whereas the longevity of egg after ovulation is $6 \sim 12$ hours. This is why horse breeders usually inseminate mares prior to ovulation. Insemination of mares after ovulation is not recommended for this reason (Andrews and McKenzie, 1941). The timing of ovulation in mares is usually anticipated by measuring the size of a dominant follicle, the color tone of the uterus and cervix, as well as estrous related behavior of the animal. However, it is still difficult to identify the precise time of ovulation, as not every mare ovulates in accordance with strictest expectations. Generally when the pre- ovulatory follicle reaches $35 \mathrm{~mm}$, ovulation can occur within approximately $24 \sim 96 \mathrm{~h}$, though this varies considerably between individual mares (Ginther, 1979b). It has also been reported that about 12 percent of ovulations occur 3 days prior to the end of estrus and about 10 percent occur after estrus has ceased(Evans, 2001). Agents that induce ovulation within a known time period are highly advantageous for this reason. Induction of ovulation can be performed using certain drugs that induce ovulation within a particular time period. Use of ovulatory agents should decrease the number of inseminations required per cycle, resulting in a higher pregnancy rate. Such agents can be used to treat mares with irregular ovulation patterns, and are also useful tools in embryo transfer programs, in synchronising ovulation timing of donors and recipients

* Corresponding author: Minjung Yoon, Division of Animal Science and Biotechnology, Kyungpook National University, Sangju, 742-711, Korea, Tel: 054-530-1233, E-mail: mjyoon@knu.ac.kr 
(Barrier-Battut et al., 2001). Studies were conducted to examine pharmacological treatment ssuch as human chorionic gonadotropin (hCG), gonadotropins, gonadotropin releasing hormone $(\mathrm{GnRH})$ agonist, equine pituitary extracts, and recombinant equine $\mathrm{LH}$ for their efficacy and accuracy in the induction of ovulation.

\section{ESTROUS CYCLE}

The estrous cycle include sestrus and diestrus stages. The average duration of the estrous cycle ranges from 19 to 22 days and it is divided into estrus (5 to 7 days) and diestrus stages (14 to 15 days) (Angus O. McKinnon and Voss, 1993a Hughes et al., 1972). Physiological changes, such as changes in reproductive organs, hormonal levels, and mare's sexual behavioral responses to the stallion, are major parameters in determining the status of the estrous cycle of mares (Angus O. McKinnon and Voss, 1993a). The season is also a critical factor in affecting the duration of estrus (Ginther et al., 1972). During summer, in the northern hemisphere, the duration of estrus is shorter than that of estrus in winter because follicular development occurs more quickly with a favorable photoperiod. In contrast, the duration of diestrus is not changeable due to the season (Angus O. McKinnon and Voss, 1993a Hughes et al., 1972).

During the estrous cycle, physiological changes in mares include follicular development, selection of the dominant follicle, release of the oocyte from follicle, formation of corpus luteum and production rates of progesterone. PGF2a lyses the corpus luteum if the mare is not pregnant, and the whole cycle initiates all over again, from follicular development. These physiological events are controlled by the endocrine system. During the breeding season, gonadotropin releasing hormone $(\mathrm{GnRH})$ is released from hypothalamus in brains. The function of $\mathrm{GnRH}$ is to stimulate the pituitary gland to produce and secrete follicle-stimulating hormone (FSH) and luteinizing hormone (LH), which are the major hormones that govern physiological events of the ovary during the estrous cycle. The important roles of the gonadotropins are to control the development of the follicle, to stimulate the secretion of estrogen from the follicle, and to induce ovulation. Other hormones such as estrogen, inhibin, activin, prolactin and insulin are also important components of the endocrine system, that control secondary ovarian events during the estrous cycle.

\section{FOLLICULAR DEVELOPMENT}

\section{Oogenesis and follicular wave}

The formation of the female gametes is initiated during early embryonic development. The origin of the oocyte, termed 'the primordial germ cell', separates from the epithelium of the yolk sac and starts migrating through the developing mesentery of the embryo, arriving in the primitive gonadal ridge (Angus O. McKinnon and Voss, 1993b). At approximately, 75 to 160 days of gestation, the oocytes enter the first meiotic division, and are arrested in meiotic prophase (Ginther, 1979a). When mares reach puberty, between 12 and 15 months, initiation of transformation of the primordial follicles from a static state to a growing pool of active follicles occur (Ginther, 1979a Wesson and Ginther, 1981).

The synchronous emergence of a cohort of follicles is called a follicular wave. There are two types of waves (major and minor) in follicular development during the estrous cycle of mares (Ginther, 1993 Ginther et al., 2003). The major wave is characterized by a divergence of follicles of a wave into dominant and subordinate follicles (Ginther, 1993). In contrast, the minor wave is characterized when there is no divergence of follicles during folliculogenesis. Major waves arealso separated into primary and secondary waves. The primary waves are characterized when a cohort of follicles emerges during diestrus. The primary waves initiate when the mean follicle size is $12.1 \pm 0.5 \mathrm{~mm}$ in diameter [on mean Day $7.4 \pm 0.5$ (Day of ovulation = Day $0)]$ (Ginther, 1993). The mean interval from divergence to ovulation was reported to be $7.2 \pm 0.4$. The follicle ovulates approximately 15 days later, when at about $45 \mathrm{~mm}$ in diameter (Ginther, 1993 Ginther et al., 2003). Secondary waves are considered when a cohort of follicles emerge during early diestrus, and the follicles become either an anovulatory follicle, or a diestrous ovulation. This secondary and minor wave occur in 8 of 34 cycles $(23.6 \%)$ and more frequently occurred during the spring than during the fall (Ginther, 1993).

FSH is a major hormone during folliculogenesis. Results from several studies indicate that FSH has a positive effect in developing the follicles of mares. Pony mares injected with an inhibin-like fraction of equine follicular fluid were associated with a low follicular development rate (Bergfelt and Ginther, 1985). Ginther (1993) reported a temporal 
correlation between the emergence of each wave and the FSH surges. Several studies were also carried out to uncover patterns of FSH levels during the estrous cycle of mares. Gastal et al. found that the peak level of FSH coincided with that period when the size of the largest follicle was about $13 \mathrm{~mm}$ (Gastal et al., 1997). After a peak of FSH, the level of FSH decreases continuously for a few days (Bergfelt and Ginther, 1992). This change in levels of FSH is critical for the selection of dominant follicles (follicular deviation) from the cohort of follicles present. Although FSH is known to be a major factor in controling the dynamics of follicular development, the emergence of the follicle can be initiated in the absence of FSH(Angus O. McKinnon and Voss, 1993b).

\section{Follicular deviation (selection of the dominant follicle)}

Follicular deviation is that process which selects a dominant follicle to ovulate,. During deviation, the largest follicle is selected as the dominant follicle, and it develops continuously. However, the growth rate of subordinate follicles decreases and their size regresses (Gastal et al., 1997). The deviation usually happens at approximately 6 days after the initiation of emergence of a 6-mm follicle, and the size of two largest follicles were reported to be approximately 22 and $19 \mathrm{~mm}$, respectively (Gastal et al., 1997). The folicles which had emerged earlier were tended to become dominant follicles, and their ranking was maintained during the common-growth phase (Ginther et al., 2004). Thus, this time advantage is the most important factor in identifying future dominant follicles during the estrous cycles of mares.

Hormones control physiological changes in mares reproductive status during the estrous cycle. Physiological changes are mainly controlled by FSH. Changes in the levels of FSH appear to be major factor for follicular deviation also. In mares, the concentration of FSH begin to decline when the size of the largest follicle reaches about $13 \mathrm{~mm}$ in diameter (3 days before deviation) (Donadeu and Ginther, 2001 Gastal et al., 1997 Ginther et al., 2004) and continue for several days, even after this deviation. This decline in levels of FSH is suggested to be a main factor in the selection of dominant follicles. It was shown that several dominant follicles can be obtained by supplying a mare with FSH. Squires et al. I (1986) injected a mare with $150 \mathrm{mg}$ of FSH-P twice daily, when the size of two or more follicles reached $20 \mathrm{~mm}$ in diameter, and until ovulation. Several dominant follicles were successfully obtained. It was suggested that low levelsof FSH at the beginning of deviation were not sufficient for the growth of every follicle in response to FSH. The largest follicle becomes more developed than other smaller follicle because it started earlier than the others. The largest follicle can survive under reduced levels of FSH, but not small follicles, which regress (Ginther et al., 2001).

Higher levels of estradiol, insulin like growth factor I (IGF-I), activin-A and inhibin-A were measured from follicular fluid of the dominant follicle and compared with the levels within the second and third largest follicles, before the beginning of deviation in mares (Donadeu and Ginther, 2002). Also, the levels of progesterone, androstenedione, IGFBP-2, and inhibin-B were different between the largest follicles and the others. Thus, these factors in follicles were suggested to play a critical roles in initiating diameter deviation.

\section{OVULATION}

The primary event during ovulation is that a mature fertilizable oocyte is released from a follicle. The dynamic process is accompanied with the resumption of meiosis and restructuring of the follicular wall. Increased pulse frequency of gonadotropin releasing hormone $(\mathrm{GnRH})$ from the hypothalamus stimulates LH release from the pituitary gland ( $\mathrm{LH}$ surge) (Pinaud et al., 1991).

\section{Roles of LH for ovulation}

LH is responsible for ovulation in mares. The functions of LH include 1) activating proteolytic enzymes, 2) enhancing synthesis of both prostaglandin E2 (PGE2) and F2a (PGF2a), and 3) stimulating the secretion of progesterone.

Follicular rupture during ovulation is initiated by the activation of proteolytic enzymes which are stimulated in response to LH. In the follicular fluid, proteolytic enzymes act to convert plasminogen to plasmin, which activates latent collagenase of follicular connective tissue. The collagenase and serine protease work to complete the proteolysis of collagen (Guraya and Dhanju, 1992). Thus, LH originally initiates a cascade of events to reduce the tensile strength of the follicular wall to a point at which rupture occurs.

PGE2 and PGF2 $a$ which are synthesized in response to 
LH play important roles in rupturing of the follicle during ovulation(Lipner and Greep, 1971). Prostaglandins trigger follicular rupture via increasing ovarian contractility, mediating hyperemia, and controlling collagen synthesis (Dennefors et al., 1983 Tjugum et al., 1983). Specifically, hyperemia of the preovulatory follicle, and increased blood flow to the follicle occur in response to increased level of PGE2 (Guraya and Dhanju, 1992 Lipner and Greep, 1971). The major process for ovulation is also controlled by increased PGF2 $a$ causing the vasoconstriction and reduction of blood flow at the apex of the follicle, as rupture of the follicle approaches (Angus O. McKinnon and Voss, 1993b).

LH stimulates the production of progesterone via stimulating the expression of genes encoding progesterone receptors (PR) (Natraj and Richards, 1993 Park and Mayo, 1991). The importance of progesterone is apparent from the result of a study showing that inhibitors of progesterone biosynthesis interfere with $\mathrm{LH}$ induction of ovulation in vivo and in vitro (Brannstrom and Janson, 1989; Lipner and Greep, 1971; Mori et al., 1977).

\section{LH surge}

The LH surge is a critical event that leads to the final stages of follicular maturation, the follicle rupture, and the expulsion of the oocyte from the follicle (Al-Inany et al., 2005). Irvine et al. (Irvine and Alexander, 1994) indicated that $\mathrm{LH}$ and FSH are secreted in the same manner as GnRH secretion, in frequent brief peaks with the same underlying periodicity during the mare's ovulatory LH surge. The result of this study suggests that the main cue for LH surge lies within the pattern of GnRH secretion.

Estradiol is also involved in initiating LH surge via its action on pituitary hormonal levels (Brook and Marshall, 1983). In human, estradiol is inhibitory factor for the secretion of gonadotropins like inhibin on pituitary level. However, the inhibitory effect of estradiol changes depending on the levels of estradiol. As the follicle develops, increased levels of estradiol are released, whereupon the higher levels of estradiol cause a temporary switch from negative to positive feedback. The positive feedback of estradiol allows for the surge of LH(Brook and Marshall, 1983). In mares, treatment with both GnRH and estradiol increase secretion of LH from pituitary cells, whereas treatment with estradiol had no effect on LH secretion (Baldwin et al., 1991). The result of this in vitro study suggested that the positive effect of estrogen was limited to GnRH-stimulated LH release.

Gonadotropins such as LH and FSH increase the production ofestradiol at the cellular level during estrous cycles. LH binds to $\mathrm{LH}$ receptors on theca cells and it stimulates the production of androgens. The androgens are diffused into the follicle and it is used as a source of estrogen by granulosa cells (Filicori and Cognigni, 2001). FSH binds to FSH receptors (FSHR) located on the membrane of granulosa cells, which leads to granulosa cell proliferation and differentiation. Furthermore, FSH stimulates aromatase system in granulose cells, which triggers the conversion of androgens to estrogens (Adashi, 1996).

\section{Ovulation in mares}

Mares exhibit unique ovulatory events, not observed in other species. An acute $24 \sim 48 \mathrm{~h}$ peak of $\mathrm{LH}$ is now observed in mares, but mares have a low surge of $\mathrm{LH}$ which initiates from approximately 6 to 7 days prior to ovulation. The peak of LH occurs 1 3 day post-ovulation. Mares' ovaries have a unique structure compared to that of other species. In most other mammals, the ovary is composed of a cortex surrounding the medulla. This structure of the ovary allows the expulsion of the oocyte at all points around the ovary as the entire ovary is lined with a germinal epithelium. In contrast, the equine ovary is reversed. Follicles develop centrally, within an ovary surrounded by a tough connective tissue capsule. Furthermore, equine ovaries contain an 'ovulation fossa', a single, discrete concave area of germinal-epithelium. The ovulation fossa is known to be the only area that allows for the expulsion of the oocyte. The ovulation fossa is thought to interfere with multiple ovulations, and to limit the number of embryos and fetuses to one or two during pregnancy.

\section{INDUCTION OF OVULATION}

A reliable ovulatory agent that triggers ovulation within certain period of time may provide huge advantages in anticipating the correct time for insemination. Several pharmacological controls (agents) such as recombinant equine LH, human chorionic gonadotropin(hCG), gonadotropins, gonadotropin releasing hormone $(\mathrm{GnRH})$ agonist, and equine pituitary extracts have been tested for their efficacy of inducing ovulation. 


\section{Equine recombinant $\mathrm{LH}$}

Single chain recombinant equine $\mathrm{LH}(\mathrm{eLH} \beta a)$ was successfully developed and tested for its efficacy in vitro and in vivo (Jablonka-Shariff et al., 2007 Yoon et al., 2007). To test the biological effect of reLH, varying levels of reLH were added to equine Leydig cell cultures and the concentrations of reLH-stimulated testosterone were compared with that of native eLH. Different levels of reFSH were also added in seminiferous tubule cultures, and estradiol production was compared to that of native eFSH. The result indicated that the biological activity of these single chain recombinants in vitro were similar to that of native equine heterodimers (Jablonka-Shariff et al., 2007).

The in vivo biological activity of reLH in stimulating the production of testosterone was tested in stallions (JablonkaShariff et al., 2007). The data showed that administration of $350 \mathrm{ul}$ reLH stimulated the release of testosterone. These data indicate that the single chain recombinant equine gonadotropins are efficient agents, and possibly can be used in assisting reproduction.

A study was conducted to test the efficacy of reLH in the induction of ovulation in mares. Mares with $35 \mathrm{~mm}$ follicles were treated with $\operatorname{reLH}(0.3,0.6,0.75,0.9 \mathrm{mg}), \operatorname{hCG}(2500$ IU), or saline as a control group, and the number of ovulations within $48 \mathrm{~h}$ of injection were monitored. With a total of 84 mares of various light horse breeds, 2 of 7 $(28.6 \%), 10$ of $20(50 \%), 9$ of $10(90 \%)$, and 16 of 20 $(80 \%)$ ovulated within $48 \mathrm{~h}$ in response to $0.3,0.6,0.75$, and $0.9 \mathrm{mg}$ reLH, respectively. The changes in hormonal profiles $\left(\mathrm{LH}, \mathrm{FSH}, \mathrm{P}_{4}, \mathrm{E}_{2}\right)$ in response to $5,0.65$ or $10 \mathrm{mg}$ reLH were similar to that of control mares treated with saline, except for the early rise in LH after injection of reLH. The result of this study indicated that reLH is an ovulatory agent that induces ovulation in mares with $35 \mathrm{~mm}$ follicle size within $48 \mathrm{~h}$. However, more studies should be carried out in order to test if this agent causes the generation of antibodies, and if its effect is consistent after multiple injections for several breeding season.

\section{2. hCG}

The hormone is produced fromcytotrophoblasts of the chorionic villi of the human placenta, and is purified with urine of pregnant women(Yen et al., 1968). Human chorionic gonadotropin (hCG) is a glycoprotein hormone composed of a non-covalently associated $a$-subunit and $\beta$ subunit (Cole and Kardana, 1992). The hCG alpha subunit is composed of 92 amino acids and the subunit is common for other pituitary glycoprotein hormones. The distinguishable biological activity of the hCG is determined by $\beta$-subunit, which is composed of 145 amino acids (Cole and Kardana, 1992). Although, the sequence of $\beta$-subunit is different, the biological function of hCG is similar to that of $\mathrm{LH}$ (Cole and Kardana, 1992). hCG is the most common agent for inducing ovulation in mares. The first application of hCG on the estrous cycle of the mare was performed with a crude extract of human pregnancy urine (prolan). The injection of prolan on the first day of estrous in mares caused ovulation 24 to $48 \mathrm{~h}$ after injection. Several experiments have been conducted to test the efficacy of hCG on inducing ovulation (Duchamp et al., 1987 Kilicarslan et al., 1996 Roser et al., 1979 Sullivan et al., 1973 Voss et al., 1974 Weissman et al., 1996 Wilson et al., 1990). The results of these studies was that 1500-3300 i.u. of hCG injections to mares with a follicle size which had reached $35 \mathrm{~mm}$ in diameter, or after a second day of estrus, induced ovulation within $48 \mathrm{~h}$. However, an adverse effect of hCG administration was also reported by several researcher. Estrous cycles of mares with the administration of hCG over 3 successive estrous cycles was monitored for any adverse effect of hCG (Sullivan et al., 1973). The result of this study indicated that the duration of estrus and ovulation time appears ineffective upon the second administration of hCG. However, the mean duration of estrus was significantly extended, and ovulation took longer after the third administration of hCG. The efficacy of hCG, after repeating the administration over two breeding seasons, was monitored (Roser et al., 1979). All mares $(n=12)$ ovulated within $48 \mathrm{~h}$ of hCG injection in the first breeding season. In the second breeding season, however, six to 17 ovulations from five mares occurred within $48 \mathrm{~h}$. During this study, 125I-labelled hCG in a modified RIA was used to determine whether or not multiple injections of hCG cause the formation of the hCG antibody. Significant levels of antibodies for hCG were also observed in 5 of the 12 mares after 2-5 injections from the first year of the study. However, the antibody is not the cause of the decreasing effect of hCG over multiple injections, because the antibody did not crossreact with equine LH. Another researcher also investigated the effect of repeated hCG administration on ovulation, over 2 years (Wilson et al., 1990). During these 2 years of hCG treatments, the estrus periods and mean ovulation time were 
shorter than in control mares. However, anti-hCG antibodies were developed in $14 / 14(100 \%)$ of the hCG treated mares. In the 2nd year of the experiment, $57.1 \%$ of mares treated with hCG had a similar ovulation rate to control mares after one to four injections. After the first 2 hCG injections, antibodies were developed in all treated mares. These results suggested that more than two injections were not to be recommended in the same year, due to immunogenicity. In contrast, no correlation between the immune response and the time of ovulation has been observed by Wilson et al. (Wilson et al., 1990). In this experiment, although antibody levels were not significantly elevated, $84.6 \%$ of the ovulations were delayed. Also $32 \%$ of ovulations occurred within $48 \mathrm{~h}$ whenin the presence of antibody. These results indicate that the immune response to hCG injection does not appear to correlate with changes in ovulation time. This suggestion was supported by the same conclusion made by Roser (1979) (Roser et al., 1979). Thus, the results suggest that the resillience of the animal towards hCG after multiple ovulations may be due to a desensitization of the follicle to hCG, rather than to a build-up of antibodies.

\section{Native $\mathrm{GnRH}$}

GnRH pulse frequency is the primary regulator of LH secretion (Alexander and Irvine, 1987). Native GnRH or its analogues can be used as an ovulatory agent, as they stimulate LH secretion, the main trigger for ovulation. GnRH has several advantages when it is used as an ovulatory agent in mares. GnRH doesn't cause an immune response after multiple administrations due to its natural origin. Also there is little risk of viral contamination because $\mathrm{GnRH}$ is a pure synthetic product. Several experiments were performed to determine the efficacy of $\mathrm{GnRH}$ in inducing ovulation in a timely fashion in cycling mares (Becker and Johnson, 1992 Irvine et al., 1975 Johnson, 1986). A single injection of 2 mg synthetic GnRH(AY-24031) was tested, but it had no effect on inducing ovulation. In contrast, daily injections of the same agent from Day 2 of estrus until ovulation, resulted in a shortening of the time period for ovulation, as well as the duration of estrus (Irvine et al., 1975). To attempt to identify a more suitable ovulatory agent, a study was performed to compare the effect between 2500 i.u. hCG and $2 \mathrm{mg}$ GnRH (native) i.m. (Duchamp et al., 1987). The 2500 i.u. hCG, injected at that time when the follicle reached $35 \mathrm{~mm}$ induced ovulation within 24 or $48 \mathrm{~h}$, whereas2 $\mathrm{mg}$ of GnRH was not significantly effective in shortening the time to ovulation when compared with control group.

Pulsatile infusion of native $\mathrm{GnRH}$ was effective in advancing the time of ovulation in cycling mares (Johnson, 1986). This result suggests that GnRH appears to be a reliable agent that can be used to induce ovulation in mares. However, administration of $4.5 \mathrm{mg} \mathrm{GnRH}$ (native) on Day 2 of estrus had no positive result in inducing ovulation, or shortening estrus (Wallace et al., 1977). Treatments with 20 ug of $\mathrm{GnRH} / \mathrm{h}$ (native) continuous infusion (CI) and its pulsatile infusion (PI) did not alter the time to ovulation after injection, or the number of ovulations. Overall, native GnRH does not appear to be a reliable agent in inducing ovulation in mares.

\section{Deslorelin (Ovuplant, GnRH-agonist)}

As an alternative ovulatory agent to $\mathrm{hCG}$, the effect of GnRH agonist on inducing timed ovulation has been suggested (Farquhar et al., 2001 McKinnon et al., 1993 Meinert et al., 1993). Deslorelin is a potent gonadotropinreleasing hormone agonist. Deslorelin was approved in the US in the form of a controlled release subcutaneous implant (Ovuplant, Fort Dodge Animal Health). The efficacy of Deslorelin has been investigated for its effect to induce ovulation in mares (Jochle, 1995 Meinert et al., 1993).

With Ovuplant, $84 \%$ and $93 \%$ of mares ovulated within 2 and 3 days of treatment, respectively (Farquhar et al., 2000). However, adverse effects have been reported for Ovuplant, when it is used as an ovulatory agent. Mares treated with Ovuplant exhibited a prolonged interovulatory interval. Treated animals experienced about 3 7 days extended estrous cycles than controls, and interestingly, the interval between ovulations in some of the mares was longer than 30 days (Morehead and Blanchard, 2000 Vanderwall et al., 2001). It was suggested that GnRH agonist may cause a downregulation of pituitary gonadotrophs (Johnson et al., 2000). In addition, a further study indicated that the suppression of follicular growth and decreased level of FSH were observed from mares treated with Ovuplant (Farquhar et al., 2001; Johnson et al., 2000). Removal of the Ovuplant after $48 \mathrm{~h}$ prevented a prolonged interovulatory interval (McCue et al., 2002). This study also observed that removal of the Ovuplant did alter ovulation rates compared to those cases where the removal of the Ovuplant had not occurred. These 
results suggested that it may be beneficial to remove the Ovuplant approximately $48 \mathrm{~h}$ after administration, in order to to prevent a prolonged interovulatory interval. However, Ovuplant is currently not commercially available.

In 2003, a short-term release deslorelin product in a biocompatible liquid vehicle (BioRelease Deslorelin Injection, BET Pharm, Lexington, KY, USA) was developed. This product releases deslorelin for approximately 6-36 h. This product has the effect of shortening the ovulation period (Fleury et al., 2004), but it is also not commercially available currently.

\section{Buserelin ( $\mathrm{GnRH}$ analogue)}

As a GnRH analogue, Buserelin was also tested for its effect of inducing ovulation in mares (Barrier-Battut et al., 2001; Ginther et al., 1972; Vidament et al., 1992). Buserelin treatment (40 ug, 4 doses at $12-\mathrm{h}$ intervals) significantly triggered ovulation without altering fertility (Barrier-Battut et al., 2001). In addition, the effect of buserelin treatments (20 ug, 4 doses at 12-h intervals; or $13.3 \mathrm{ug}, 3$ doses at 6-h intervals) was comparable with hCG treatment (2,500 IU, iv). Increases in levels of $\mathrm{LH}$ were also observed during a 48-h period when compared to the control. However, some inefficiencies of buserelin in inducing ovulation was also reported (Camillo et al., 2004). Mares treated with Buserelin (40 ug IV, twice daily), hCG(2500 IU, single IV) and placebo ( $2 \mathrm{ml}$ in distilled water IV) were compared, in order to determine the effect of buserelin on inducing ovulation. The highest ovulation rate was found in hCG treatments which resulted in $88 \%$ of mares ovulatinge between 36 and $48 \mathrm{~h}$, but groups treated with Buserelin caused just $22.7 \%$ of treated mares to ovulate within $48 \mathrm{~h}$. In this study, $5.3 \%$ mares in the control group ovulated within the same timeframe. The results of this study suggested that buserelin is not as efficient an agent as hCG in inducing ovulation in mares.

\section{Equine Pituitary Extracts}

The Equine pituitary is an gland which produces FSH and LH. The extract crude equine gonadotropin (CEG) from the pituitary also contains both FSH and LH. These extracts have been tested to determine whether they can be used as agents for controlling estrous cycles of mares. Because of its $\mathrm{LH}$ content, testing the effect of CEG on inducing ovulation was necessary. Ponies and mares were used to test its effect on inducing ovulation (Duchamp et al., 1987). $80 \%$ percent of ponies and $57 \%$ of mares ovulated within 2 days in response to $50 \mathrm{mg}$ and $25 \mathrm{mg} \mathrm{CEG}$, respectively. However, there are several obstacles towards the use of CEG as a major agent in inducing ovulation in mares. For commercial use, CEG is not easy to obtain and is expensive, 2) the FSH and LH ratio in CEG is not always consistent, which may vary the resultsof its use. Also CEG may be contaminated with other hormones from the pituitary. Presently, CEG is not readily commercially available.

\section{Equine chorinoic gonadotropin (eCG or PMSG)}

eCG is secreted by trophoblastic cells of the mare between the $36^{\text {th }}$ to $120^{\text {th }}$ day of gestation (Allen and Moor, 1972; McKinnon and Voss, 1992). In 1930, eCG was discovered, and its effect on the sexual maturity of the immature rat was tested (Cole and Hart, 1930) (ED: what was the result?). In pregnant mares, eCG was originally considered to have a function as the principal luteotrophic agent during the first half of equine pregnancy. However, eCG is a pituitary gonadotropin which stimulates the secondary follicular growth and ovulation, to cause the formation of accessory luteal tissue (Allen, 1975; Evans and Irvine, 1975). In mares, there is no positive effect of eCG on follicular development and ovulation (Day, 1940, 1939), although eCG has been widely used to induce superovulation in several mammalian species due to its containing both LH and FSH (Butt et al., 1970 Rowson, 1971). The reason eCG is does not function in mares has been unveiled by Stewart and Allen (Stewart and Allen, 1979). The binding affinity of PMSG to LH receptors from mares was approximately $10 \%$ of that to $\mathrm{LH}$ receptors from other species. Furthermore, PMSG did not have a binding affinity to the equine FSHreceptor (Stewart and Allen, 1979), suggesting that the secondary follicles, during early equine pregnancy, were stimulated not by PMSG, but by waves of maternal pituitary FSH(Evans and Irvine, 1975). Therefore, eCG is not useful material in the induction of ovulation in mares due to its lack of affinity to the gonadotropin receptors of mares, however, eCG remains to be widely used to induce ovulation in other species.

\section{CONCLUSION}

Mares are very unique creatures. Mares show a different 
pattern of estrous cycle and ovulation events when compared to that of other species. Therefore, understanding the unique physiological conditions and reproductive eventsof mares is necessary to improve their pregnancy rates. Controlling the time of ovulation enhances conception rates in mares. Accordingly, several agents including hCG, GnRH, GnRHagonist, GnRH-analog, equine pituitary extract have been investigated for their efficacy in inducing ovulation. Although some of these agents shorten the time of ovulation to within $48 \mathrm{~h}$, alternatives are continuously being sought. Recently, reLH was successfully developed and its biological activity was proved by in vitro and in vivo studies (Jablonka-Shariff et al., 2007; Yoon et al., 2007). This agent appears to be a reliable tool in inducing ovulation within $48 \mathrm{~h}$ after injection. Using reLH, the correct time to inseminate can be determined, and this technique should lead to higher pregnancy ratesof mares.

The use of advanced reproductive techniques can lead to major economic benefits for equine breeding farms. More studies are warranted to improve such assisted reproductive techniques in horses, in order to increase the fertility rates in mares.

\section{REFERENCES}

Adashi, E. Y. 1996. The ovarian follicular apparatus. LippincottRaven, Philadelphia.

Al-Inany, H. G., Aboulghar, M., Mansour, R. and Proctor, M. 2005. Recombinant versus urinary human chorionic gonadotrophin for ovulation induction in assisted conception. Cochrane Database Syst Rev: CD003719.

Alexander, S. L. and Irvine, C. H. 1987. Secretion rates and short-term patterns of gonadotrophin-releasing hormone, FSH and LH throughout the periovulator yperiod in the mare. J Endocrinol 114:351-362.

Allen, W. E. 1975. Ovarian changes during early pregnancy in pony mares in relation to PMSG production. J Reprod Fertil Suppl: 425-428.

Allen, W. R. and Moor, R. M. 1972. The origin of the equine endometrial cups. I. Production of PMSG by fetal trophoblast cells. J Reprod Fertil 29:313-316.

Andrews, F. and McKenzie, F. 1941. Estrus, Ovulation and Related Phenomena in the Mare. University of Missouri-Columbia.

Angus O. McKinnon and Voss, J. L. 1993a. Equine reproduction. Williams \& Wilkins, Media, PA.

Angus O. McKinnon and Voss, J. L. 1993b. Equine reproduction.
Williams \& Wilkins, Media, PA.

Baldwin, D. M., Roser, J. F., Muyan, M., Lasley, B. and Dybdal, N. 1991. Direct effects of free and conjugated steroids on GnRH stimulated LH release in cultured equine anterior pituitary cells. J Reprod Fertil Suppl 44:327-332.

Barrier-Battut, I. et al. 2001. Use of buserelin to induce ovulation in the cyclic mare. Theriogenology 55:1679-1695.

Becker, S. E. and Johnson, A. L. 1992. Effects of gonadotropinreleasing hormone infused in a pulsatile or continuous fashion on serum gonadotropin concentrations and ovulation in the mare. J Anim Sci 70:1208-1215.

Bergfelt, D. R. and Ginther, O. J. 1985. Delayed follicular development and ovulation following inhibition of FSH with equine follicular fluid in the mare. Theriogenology 24:99-108.

Bergfelt, D. R. and Ginther, O. J. 1992. Relationships between circulating concentrations of FSH and follicular waves during early pregnancy in mares. Equine Vet Sci. 12:274-279.

Brannstrom, M. and Janson, P. O. 1989. Progesterone is a mediator in the ovulatory process of the in vitro-perfused rat ovary. Biol Reprod 40:1170-1178.

Brook, C. G. D. and Marshall, N. J. 1983. Essential Endocrinology. Fourth edition ed. The Blackwell Science Ltd., Bodmin, Cornwall.

Butt, W. R., Crooke, A. C. and Ryle, M. 1970. Gonadotrophins and ovarian development, Livingstone, Edinburgh.

Camillo, F. et al. 2004. Clinical use of twice daily injections of buserelin acetate to induce ovulation in the mare. Vet Res Commun 28 Suppl 1:169-172.

Cole, H. H. and Hart, G. H. 1930. The potency of blood serum of mares in progressive stages of pregnancy in effecting the sexual maturity of the immature rat. Am. J. Physiol. 80:57-68.

Cole, L. A. and Kardana, A. 1992. Discordant results in human chorionic gonadotropin assays. Clin Chem 38:263-270.

Day, F. T. 1939. Ovulation and the descent of the ovum in the fallopian tube of the mare after treatment with gonadotrophic hormones. J. agric. Sci. Camb. 29:459-469.

Day, F. T. 1940. Clinical and experimental observations on reproduction in the mare. J. Agric. Sci. Camb. 30:244-261.

Dennefors, B. et al. 1983. Aspects concerning the role of prostaglandins for ovarian function. Acta Obstet Gynecol Scand Suppl 113:31-41.

Donadeu, F. X. and Ginther, O. J. 2001. Effect of number and diameter of follicles on plasma concentrations of inhibin and FSH in mares. Reproduction 121:897-903.

Donadeu, F. X. and Ginther, O. J. 2002. Changes in concentrations of follicular fluid factors during follicle selection in mares. 
Biol Reprod 66:1111-1118.

Duchamp, G., Bour, B., Combarnous, Y. and Palmer, E. 1987. Alternative solutions to hCG induction of ovulation in the mare. J Reprod Fertil Suppl 35:221-228.

Evans, J. W. 2001. Horses. 3th ed. Henry Holt, New York.

Evans, M. J. and Irvine, C. H. 1975. Serum concentrations of FSH, LH and progesterone during the oestrous cycle and early pregnancy in the mare. J Reprod Fertil Suppl: 193-200.

Farquhar, V., PM, M., DK, V. and EL, S. 2000. Efficacy of the GnRH agonist deslorelin acetate for inducing ovulation in mares relative to age of mare and season. J Equine Vet Sci. 20:8-11.

Farquhar, V. J., McCue, P. M., Nett, T. M. and Squires, E. L. 2001. Effect of deslorelin acetate on gonadotropin secretion and ovarian follicle development in cycling mares. J Am Vet Med Assoc 218:749-752.

Filicori, M. and Cognigni, G. E. 2001. Clinical review 126: Roles and novel regimens of luteinizing hormone and folliclestimulating hormone in ovulation induction. J Clin Endocrinol Metab 86:1437-1441.

Fleury, P. D. C., Alonso, M. A., Alvarenga, M. A. and Douglas, R. H. 2004. Intervals to ovulation after treatment with oestradiol cypionate (ECP) or biorelease deslorelin (BRT-DES). In: Proceedings of the 6th International Symposium on Equine embryo transfer, Rio de Janeiro, Brazil.

Gastal, E. L., Gastal, M. O., Bergfelt, D. R. and Ginther, O. J. 1997. Role of diameter differences among follicles in selection of a future dominant follicle in mares. Biol Reprod 57: 1320-1327.

Ginther, O. J. 1979a. Reproductive biology of the mare Madison, Wisconsin.

Ginther, O. J. 1979b. Reproductive biology of the mare, Madison, Wisconsin.

Ginther, O. J. 1993. Major and minor follicular waves during the equine estrous cycle. Journal of Equine Veterinary Science $18-25$.

Ginther, O. J., Beg, M. A., Bergfelt, D. R., Donadeu, F. X. and Kot, K. 2001. Follicle selection in monovular species. Biol Reprod 65:638-647.

Ginther, O. J., Beg, M. A., Gastal, M. O. and Gastal, E. L. 2004. Follicle dynamics and selection in mares. Anim Reprod. 1: 45-63.

Ginther, O. J., Whitmore, H. L. and Squires, E. L. 1972. Characteristics of estrus, diestrus, and ovulation in mares and effects of season and nursing. Am J Vet Res 33:1935-1939.

Ginther, O. J., Woods, B. G., Meira, C., Beg, M. A. and
Bergfelt, D. R. 2003. Hormonal mechanism of follicle deviation as indicated by major versus minor follicular waves during the transition into the anovulatory season in mares. Reproduction 126:653-660.

Guraya, S. S. and Dhanju, C. K. 1992. Mechanism of ovulationan overview. Indian J Exp Biol 30:958-967.

Hughes, J. P., Stabenfeldt, G. H. and Evans, J. W. 1972. Estrous cycle and ovulation in the mare. J Am Vet Med Assoc 161: 1367-1374.

Irvine, C. H. and Alexander, S. L. 1994. The dynamics of gonadotrophin-releasing hormone, LH and FSH secretion during the spontaneous ovulatory surge of the mare as revealed by intensive sampling of pituitary venous blood. J Endocrinol 140:283-295.

Irvine, D. S., Downey, B. R., Parker W. G. and Sullivan, J. J. 1975. Duration of oestrus and time of ovulation in mares treated with synthetic Gn-RH(AY-24,031). J Reprod Fertil Suppl: $279-283$.

Jablonka-Shariff, A. et al. 2007. Expression and bioactivity of a single chain recombinant equine luteinizing hormone (reLH). Theriogenology 67:311-320.

Jochle, W. 1995. [Control of ovulation in the mare with Ovuplant (short-term release of the GnRH analog deslorelin acetate). Overview of investigations from 1990 to 1994]. Tierarztl Prax 23:381-393.

Johnson, A. L. 1986. Induction of ovulation in anestrous mares with pulsatile administration of gonadotropin-releasing hormone. Am J Vet Res 47:983-986.

Johnson, C. A., Thompson, D. L., K. M. K. Jr. and Guitreau, A. M. 2000. Prolonged interovulatory interval and hormonal changes in mares following the use of OvuplantTM to hasten ovulation. J. Equine Vet. Sci. 20:331336.

Kilicarslan, M. R. et al. 1996. Effect of GnRH and hCG on ovulation and pregnancy in mares. Vet Rec 139:119-120.

Lipner, H. and Greep, R. O. 1971. Inhibition of steroidogenesis at various sites in the biosynthetic pathway in relation to induced ovulation. Endocrinology 88:602-607.

McCue, P. M., Farquhar, V. J., Carnevale, E. M. and Squires, E. L. 2002. Removal of deslorelin (Ovuplant) implant $48 \mathrm{~h}$ after administration results in normal interovulatory intervals in mares. Theriogenology 58:865-870.

McKinnon, A. O. et al. 1993. Predictable ovulation in mares treated with an implant of the GnRH analogue deslorelin. Equine Vet J 25:321-323.

McKinnon, A. O. and Voss, J. L. 1992. Equine reproduction. Williams \& Wilkins, Media, PA. 
Meinert, C. et al. 1993. Advancing the time of ovulation in the mare with a short-term implant releasing the GnRH analogue deslorelin. Equine Vet J 25:65-68.

Morehead, J. and Blanchard, T. 2000. Clinical experience with deslorelin (Ovuplant ${ }^{\mathrm{TM}}$ ) in a Kentucky Thoroughbred broodmare practice (1999). J Equine Vet Sci. 20:358402.

Mori, T., Suzuki, A., Nishimura, T. and Kambegawa, A. 1977. Inhibition of ovulation in immature rats by anti-progesterone antiserum. J Endocrinol 73:185-186.

Natraj, U. and Richards, J. S. 1993. Hormonal regulation, localization, and functional activity of the progesterone receptor in granulosa cells of rat preovulatory follicles. Endocrinology 133:761-769.

Park, O. K. and Mayo, K. E. 1991. Transient expression of progesterone receptor messenger RNA in ovarian granulosa cells after the preovulatory luteinizing hormone surge. Mol Endocrinol 5:967-978.

Pinaud, M. A., Roser, J. F. and Dybdal, N. 1991. Gonadotropin releasing hormone $(\mathrm{GnRH})$ induced luteinizing hormone $(\mathrm{LH})$ secretion from perifused equine pituitaries. Domest Anim Endocrinol 8:353-368.

Roser, J. F., Kiefer, B. L., Evans, J. W., Neely, D. P. and Pacheco, D. A. 1979. The development of antibodies to human chorionic gonadotrophin following its repeated injection in the cyclic mare. J Reprod Fertil Suppl: 173-179.

Rowson, L. E. 1971. Egg transfer in domestic animals. Nature 233:379-381.

Squires, E. L., Garcia, R. H., Ginther, O. J., Voss, J. L. and Seidel, G. E. 1986. Comparison of equine pituitary extract and follicle stimulating homone for superovulating mares. Theriogenology 26:661-670.

Stewart, F. and Allen, W. R. 1979. The binding of FSH, LH and PMSG to equine gonadal tissues. J Reprod Fertil Suppl: 431-440.

Sullivan, J. J., Parker, W. G. and Larson, L. L. 1973. Duration of estrus and ovulation time in nonlactating mares given human chorionic gondotropin during three successive estrous periods. J Am Vet Med Assoc 162:895-898.
Tjugum, J., Norstrom, A. and Dennefors, B. 1983. Influence of prostaglandin E2 on proteoglycan synthesis in the human ovarian follicle wall. Prostaglandins 25:71-77.

Vanderwall, D. K., Juergens, T. D. and Woods, G. L. 2001. Reproductive performance of commercial broodmares after induction of ovulation with hCG or Ovuplant(deslorelin). J. Equine Vet. Sci. 21:539-542.

Vidament, M., Arnaud, G., Trillaud-Geyl, C., Duchamp, G. and Palmer, E. 1992. Analogue of GnRH (buserelin) and of PGF2a do not induce ovulation in mares. Proceedings of the 12th International Congress Animal Reproduction and Artificial Insemination, The Hague 4:1927-1929.

Voss, J. L., Pickett, B. W., Burwash, L. D. and Daniels, W. H. 1974. Effect of human chorionic gonadotropin on duration of estrous cycle and fertility of normally cycling, nonlactating mares. J Am Vet Med Assoc 165:704-706.

Wallace, R. A., Squires, E. L., Voss, J. L. and Pickett, B. W. 1977. Effectiveness of GnRH or GnRh analogues in inducing ovulating and shortening estrus in mares. In: 69th Annu Meet Anim Sci. Abstr\# 535, Madison WI.

Weissman, A., Lurie, S., Zalel, Y., Goldchmit, R. and Shoham, Z. 1996. Human chorionic gonadotropin: pharmacokinetics of subcutaneous administration. Gynecol Endocrinol 10:273-276.

Wesson, J. A. and Ginther, O. J. 1981. Influence of season and age on reproductive activity in pony mares on the basis of a slaughterhouse survey. J Anim Sci 52:119-129.

Wilson, C., Downie, C. and Hughes, J. 1990. Effects of repeated hCG injections on reproductive efficiency in mares. J Equine Vet Sci. 10:301-308.

Yen, S. S., Llerena, O., Little, B. and Pearson, O. H. 1968. Disappearance rates of endogenous luteinizing hormone and chorionic gonadotropin in man. J Clin Endocrinol Metab 28: 1763-1767.

Yoon, M. J. et al. 2007. The efficacy of a single chain recombinant equine luteinizing hormone $(\mathrm{reLH})$ in mares: induction of ovulation, hormone profiles, and inter-ovulatory intervals. Domest Anim Endocrinol 33:470-479.

(Received Jun. 7, 2012; Revised Jun. 11, 2012; Accepted Jun. 14, 2012) 